\title{
The use of collaborative strategic reading to improve students' reading comprehension.
}

\author{
Porti Rosenna Br Manjorang ${ }^{1}$, Ujang Suparman ${ }^{2}$, Burhanuddin $^{3}$ \\ English Education Study Program, University of Lampung ${ }^{1,2,3}$ \\ ${ }^{1}$ Correspondence: Portimanjorang1010@gmail.com
}

\begin{abstract}
The objectives of this research was to find out whether there was a statistically significant difference of students' reading comprehension ability of narrative texts after the students were taught through CSR strategy and also to find out which aspect of reading comprehension improves the most after CSR was implemented in teaching reading at the tenth grade of SMKN 1 Terbanggi Besar. This research was a quantitative research and the method was one group pre-test and post-test design. In pre-test students mean score was 52.17 while in post-test it increase to 76.15 ; the gain obtained in pre-test to post-test is 23.98. The subjects of the research were 26students at the tenth grade of SMKN 1 Terbanggi Besar. The reading comprehension test was used as the research instrument. The data were analyzed using paired sample t-test. The result showed that there was a statistically significant difference of students' reading comprehension of narrative texts. Determining main idea was the aspect that improved the most after implementing Collaborative Strategic Reading technique.
\end{abstract}

Keywords: reading comprehension, CSR strategy, and narrative text.

\section{I.INTRODUCTION}

In English Language there are four basic skills that students must master, one of those skills is reading. The purpose of teaching reading is to make the students able to read the text effectively. Therefore, students can get the information from the text they read and learn not only to understand the structure of the texts but also to comprehend the content of the texts. According to Harmer(2004) the reading skills should be acquired by students. They need to be able to scan a text and skim a text to get general idea of the text that they read. Both teachers will expect them to be more utilitarian with literary work when reading comprehension.

McDonough \& Christopher (1993)istate "reading is the most important foreign language skill". It means that reading is one of the most important skills for English language learners, especially for students who learn English as a foreign language. Unfortunately, reading is considered as a difficult foreign language skill for students, this is true because reading has many complex components. According to Nuttal(1985) there are five aspect of reading, such as: (1) main idea refers to the important information about the overall idea of a text, (2) specific information refers to the facts or ideas that explain or prove the main idea, (3) inference refers to a good guess or conclusion based on logic of passage, (4) reference refers to a word or phrase used either before or after the reference, and (5) vocabulary refers to all the words which exist in particular or object.

In reality, reading is considered as a boring activity for the students because based on the observation during the field practice program at SMKN 1 Terbanggi Besar, it was found that the students 
experienced difficulty to comprehend the text. The result of observation showed that there were some problems faced by the students in learning reading. The students faced the difficulty in constructing the idea of the text, especially in getting the main idea, finding specific information, finding reference, and making inference. The students also were lack of vocabulary. Consequently, the students are unable to answer the questions of reading test because they could not understand what they have read. To be more concrete, according to Agustiara(2014) in her research at SMPN 13 Bandar Lampung found that the students still faced some difficulties in answering the questions in English especially in reading comprehension.

Nowadays, many teaching strategies were offered to facilitate the teacher in improving the students' reading ability. One of those strategies in teaching reading which guides the students for being able to collaborate well with others is Collaborative Strategic Reading (CSR). In view of this, (Klingner \& Vaughn, 1998) state CSR is a collaborative strategy that teaches students to use the comprehension strategies while working cooperatively. According to (Klingner et al., 2004)CSR helps students learn some specific strategies such as learning in a cooperative environment, brainstorming and predicting (Preview), monitoring understanding (Click and Clunk), finding the main idea (Get the Gist), and answering questions (Wrap up). By doing these activities, the students are not only encouraged to work together in comprehending the text but also maximize their involvement and responsibility to understand the text well.

Regarding the issue above, a lot of researches have conducted for finding the effect of Collaborative Strategic Reading (CSR) technique in teaching English especially in teaching reading. A research Conducted by Puspita(2012)at the second grade of SMP Negeri 1 Ngadirojo in the Academic Year of 2011/2012. The research findings showed that the use of CSR improve students' reading classroom situation of English class. The improvement of classroom situation during teaching learning process occurred include: (1) all studentsgaves more attention when teaching learning process conducted, (2) students' behavior change as a whole and they do not do the useless activity during the lesson, (3) the students were more active during teaching learning process, (4) they were more responsible to do the task.

According toSusana et al.,( 2020). This research was to improve students' reading comprehension using Collaborative Strategic Reading. The method used in this research is experimental research with one group pre-test posttest design. Data collection techniques were tests and observation. Data analysis technique used is Paired Sample T-test. The result shows that the average value of the post-test reading comprehension was higher than the results of the pretest reading comprehension $(81,250>51,875)$. In addition, the significance value obtained was 0,000 or the significance value was smaller than the significance standard of 0.05 ( $\mathrm{sig}<0.05$ ). Thus, it indicates that Collaborative Strategic Reading (CSR) learning model can improve reading comprehension students of English Education in Islamic University of Malang.

According to the explanation above, the researcher would be apply CollaborativeStrategy Reading in teaching reading narrative text because CSR is suitable strategy that could help the students to comprehend the text well. The researcher also had a thought in assuming the theories that CSR would begiven opportunity for the students to understand deeper about the text easily. Besides to produce students' comprehension, by applying this strategy was expected to make the students more active,they 
easily share idea with other students and they easly to comprehend the text well. It was hoped that this strategy can overcome the students' problem in reading. This research is intended to find out whether there is a significant difference od students' reading comprehension ability in narrative text after being taught by using CSR. There are basically five aspects of reading in this research: (1) main idea, (2) spesific information, (3) vocabulary, (4) inference, and (5) reference (Nuttal, 1985).

Based on these problems and reasons, the researcher would like to found out significants differences of students' reading comprehension and the researcher would like to found out about what aspect that improved the most after being taught by CSR in reading comprehension.

\section{II.METHODOLOGY}

In conducting this research, the researcher used a quantitative research by applying One Group PretestPosttest design. This research has beenconductedin five meetings. One meeting has be for conducting pretest,and posttest (T1) will be given before the researcher taught by using CSR in order to measure the students' reading ability before they were given the treatment. Then, three meetings were for treatment (X) to teach reading by using CSR in order to improve students' reading comprehension. The last, one meeting was for conducting pre-test(T1), and posttest (T2) would be given after implementing CSR and to measure how far the students' improvement of reading ability after they got the treatments. The experiment class in this study could be described as follows:

\section{T1 X T2}

The formula can be further illustrated as follows:

T1: refers to Pre-test

$\mathbf{X}$ : deals with treatments (Using CSR)

T2: relates to Post-Test

\section{Population and Sample}

(Hatch \& Farhady, 1982)

The population of this research was the tenth grade students at SMKN 1 TerbanggiBesar in the 2021/2022 academic year. The sample was the students in X accounting 1 class which consists of 26 students. The sample was choosen by using random sampling so that all the population class has the same opportunity to be research sample.

\section{Research Instrument}

Research instruments were tools or facilities used by researchersin collecting data so that their work was easier with the results were better, in a more accurate, completeand systematic sensemore easier toprocess (Arikunto,2011). There were two instruments used in this research mentioned as follows:

\section{Pre-test}

Pretest would be conducted to measure the students' reading ability in comprehending the text before the treatments. 


\section{Post-test}

Posttest would be conducted in order to find out how far students' improvement in reading comprehension after conducting the treatment by using CSR.

\section{RESULT AND DISCUSSION}

\section{The Result of the Pre-test}

The pre-test was administered in the experimental class before they were given the treatment. There were 30 items that have been tested. To investigate students' reading comprehension ability, the result of the result pre-test was calculated manually through Microsoft Excel and further be statistically analyzed by using SPPS 20. The result showed that the total of pre-test was 1336.57 . The mean of the pre-test was 52.17.

\section{The Result of the Post-test}

The post test was administered in to investigate whether or not there is a significant improvement after the implementation of Collaborative Strategic Reading. There were 30 items of post-test that have been tested.

The result showed that the total of the post-test was 1979.91. The mean of post-test 76.15.

Table 1The Gain of Students' Pre-test and Post-test

\begin{tabular}{|lll|}
\hline Mean score of Pre-Test & Mean Score of Post-Test & Gain \\
\hline 52,17 & $\mathbf{7 6 . 1 5}$ & 23,98 \\
\hline
\end{tabular}

As could be seen in table, it is clear that the students' reading comprehension ability increased significantly. It can be seen from the result of thepre-test mean (52.17) and compared to the post-test mean (76.15) which obtain the gain 23.98 .

\section{Normality Test}

The data should be tested the normality to determine whether the data were distributed normally or not. In other words, the researcher used One-Sample Kolmogorov-Smirnov Formula through SPSS. The data was said normal if the result higher than 0,05 . The result of pre test and post-test normally is presented as follows 
Table 2. Normality Test Result

One-Sample Kolmogorov-Smirnov Test

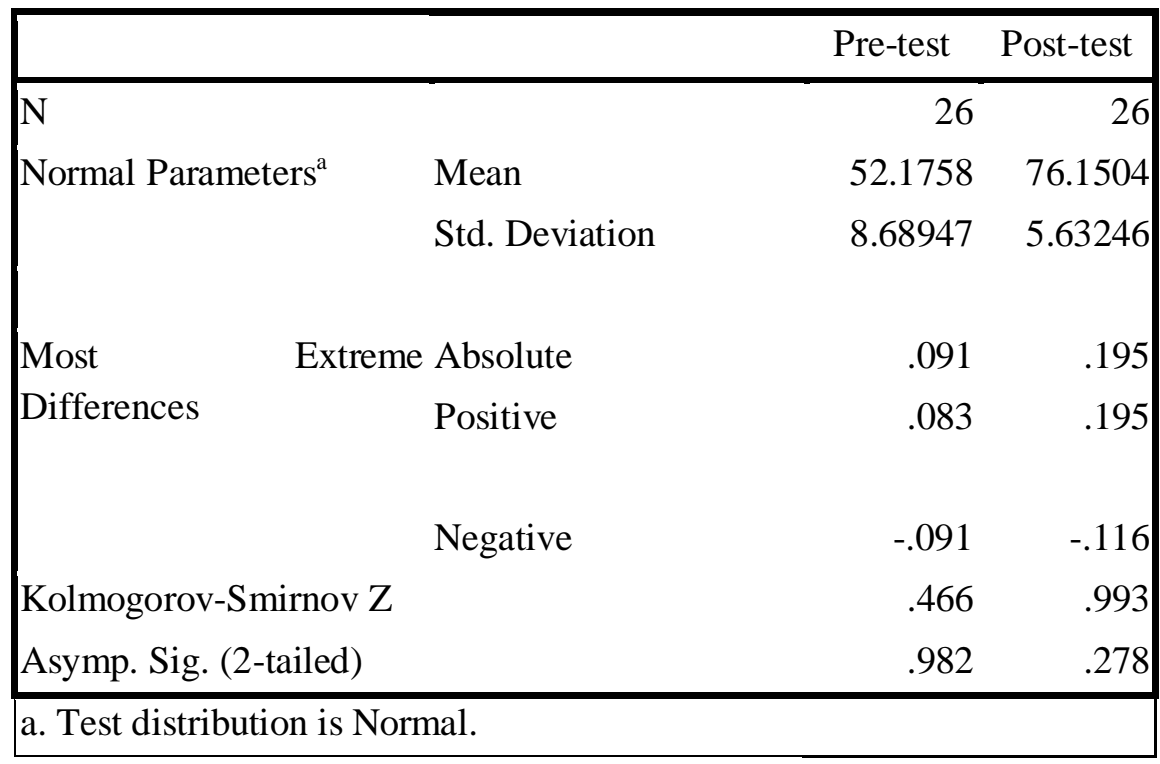

From the Table of One-Sample Kologorov-Smirnov Test above, as can be seen that the significance value (2-tailed) of the normality of the normality test pre-test was 0.982 and post-test was 0,278 which were higher than0.05. Thus, it can be inferred that the data were distributed normally.

\section{Hypothesis Testing}

In proving whether the hypothesis proposed by the researcher is accepted or not. Paired-Sample T-Test (SPSS 160 for windows) was used to test the hypothesis in which the significance was determined if the result is lower than 0,05 . The data of hypothesis testing is presented as follows:

Table3. Hypothesis Testing

\begin{tabular}{|c|c|c|c|c|c|c|c|c|c|}
\hline \multicolumn{10}{|c|}{ Paired Samples Test } \\
\hline & & \multicolumn{6}{|c|}{ Paired Differences } & \multirow{3}{*}{$\begin{array}{l}\mathrm{D} \\
\mathrm{f}\end{array}$} & \multirow{3}{*}{$\begin{array}{l}\text { Sig. } \\
(2- \\
\text { tailed } \\
)\end{array}$} \\
\hline & & \multirow[t]{2}{*}{ Mean } & \multirow[t]{2}{*}{$\begin{array}{l}\text { Std. } \\
\text { Deviatio } \\
n\end{array}$} & \multirow[t]{2}{*}{$\begin{array}{l}\text { Std. } \\
\text { Error } \\
\text { Mean }\end{array}$} & \multicolumn{2}{|c|}{$\begin{array}{l}95 \% \text { Confidence } \\
\text { Interval of the } \\
\text { Difference }\end{array}$} & \multirow[t]{2}{*}{$\mathrm{T}$} & & \\
\hline & & & & & $\begin{array}{l}\text { Lowe } \\
\mathrm{r}\end{array}$ & $\begin{array}{l}\text { Uppe } \\
\mathrm{r}\end{array}$ & & & \\
\hline $\begin{array}{l}\text { Pair } \\
1\end{array}$ & $\begin{array}{l}\text { Postt } \\
\text { est - } \\
\text { Prete } \\
\text { st }\end{array}$ & $\begin{array}{l}2.397 \\
46 \mathrm{E} 1\end{array}$ & 8.05712 & $\begin{array}{l}1.580 \\
13\end{array}$ & $\begin{array}{l}20.72 \\
027\end{array}$ & $\begin{array}{l}27.22 \\
896\end{array}$ & 15.173 & 25 & .000 \\
\hline
\end{tabular}

Table 4.8 showed that the result of the computation of the value of two-tailed significance was 0.000 . It 
mean that $H_{l}$ was accepted and $H_{0}$ was rejected since $0.00<0.05$. Then, if the t-value $(15.173)$ compared with $t$ table (2.059), it can be seen that $t$-value> $t$-table $(15.173>2.059)$ which mean that $\mathrm{H}_{0}$ is rejected and $\mathrm{H}_{1}$ is accepted. In conclusion, based on the result of sig 2-tailed and t-value of Paired Sample T-Test, it could be said that Collaborative Strategic Reading give significant difference of students' reading comprehenshion.

\section{The Result of Students' Reading in Each Aspect of Reading}

Meanwhile, the second result of the research shows the improvement of all reading aspects. The summary can be seen from the following table below.

Table 4. Improvement of Each Aspect in Reading Comprehension

\begin{tabular}{|lllll|}
\hline $\begin{array}{c}\text { Aspect of Reading } \\
\text { Comprehension }\end{array}$ & \multicolumn{1}{c}{$\begin{array}{c}\text { Mean Score } \\
\text { of } \\
\text { Pre-Test }\end{array}$} & \multicolumn{1}{c|}{$\begin{array}{c}\text { Mean Score } \\
\text { of } \\
\text { Post-Test }\end{array}$} & Gain & Percentage \\
\hline Main idea & $\mathbf{1 3 . 3 3}$ & $\mathbf{2 2 . 5}$ & $\mathbf{9 . 1 7}$ & 35 \\
\hline Specific Information & $\mathbf{1 2 . 3 3}$ & $\mathbf{1 9 . 8 3}$ & 7.5 & $\mathbf{2 8}$ \\
\hline Inference & $\mathbf{1 3 . 1 6}$ & $\mathbf{1 8 , 8 3}$ & $\mathbf{5 . 6 7}$ & $\mathbf{2 1}$ \\
\hline Reference & $\mathbf{1 4}$ & $\mathbf{1 5}$ & $\mathbf{1}$ & $\mathbf{4}$ \\
\hline Vocabulary & $\mathbf{1 3 . 5}$ & $\mathbf{2 1 . 5}$ & $\mathbf{8}$ & 30 \\
\hline Total & $\mathbf{6 6 . 3 2}$ & $\mathbf{9 7 . 6 6}$ & 31.34 & \\
\hline
\end{tabular}

In relation to Table 4 above, CSR improves the students' reading comprehension ability in all aspects of reading comprehension, such as identifying main idea which gained to 9.17 , finding specific information which was 7.5, making inference which gained to 5.67, determining reference which was 1 , and understanding vocabulary which gained to 8. Moreover, CSR mostly improves students' reading comprehension in identifying main idea, in which their ability in that aspect is 9.17 improved significantly.

\section{CONCLUSIONS AND SUGGESTIONS}

In the final analysis, Collaborative Strategic Reading can give significant differences to students reading comprehension. Based on the result, there is a significant difference of students reading comprehension after being taught using Collaborative Strategic Reading in narrative text at SMKN 1 TerbanggiBesar . It was proved by the increase of students mean score in the post-test which is higher than in the pre-test. Students' mean scores in the pre-test was 52.17 and post-test was 76.17 in which the gain was 23.98. Moreover, the result of Paired Sample T-Test was proved to decide which hypothesis should been accepted or rejected. In the result of hypothesis testing, the sig 2-tailed was 0.000 which was lower than the level of significance 0.05 . Besides, the highest improvement aspect of reading comprehension after being taught by using CSR was finding main idea. Most of all, CSR can be applied as the alternative strategy to motivate the students which enables to help them to achieve the goals of learning process of reading. 
In reference to the conclusion above, the researcher recommends some suggestions as follow: First, Suggestions for English Teachers As can be seen that the lower two aspects of reading comprehension ability were reference and vocabulary, it is necessary for the English teacher to improve students' understanding of reference and vocabulary by providing exercises: (1) in terms of reference, the teacher can explain about pronoun to the students. (2) in terms of vocabulary, the teacher can teach the students by guessing the meaning of the words through picture and making the antonym or the synonym in written card. Furthermore, in applying CSR, the teacher should control the students' activities and consider the time allocation to make the efficiency of the strategy itself.

Second, Suggestions for Further Researchers Since this research was conducted using CSR to improve students' reading comprehension ability, further researchers, can try to use this strategy to improve students' reading comprehension for different levels of students such as junior high school students, or even university level. After all, further researchers can apply this strategy by using other kinds of text, i.e. descriptive, report, recount, and explanation.

\section{REFERENCES}

Agustiara, Y. (2014). Improving reading comprehension through get the gist strategy at the second grade of SMP Bandar Lampung. Universitas Lampung.

Harmer, J. (2004). How to teach English. Cambridge: Longman.

Hatch, E., \& Farhady, H. (1982). Resign design and statistics for applied linguistics. Newbury House Publishers Inc.

Klingner, J. K., \& Vaughn, S.(1998). Using collaborative strategic reading. Teaching Exceptional Childern, 30(6), 32-37.

Klingner, J. K., Vaughn, S., Arguelles, M. E., Hughes, M. T., \& Leftwich, S. A. (2004). Collaborative strategic reading "realworld" lessons from classroom teachers. Remedical and Special Education, 25(5), 291-302.

McDonough, J., \& Christopher, S. (1993). Materilas and methods in ELT: a teachers' guide. Blackwell Publishers.

Nuttal, C. (1985). Teaching reading skill in a foreign language. British library.

Puspita, E. D. (2012). Improving students' reading comprehension using collaborative strategic reading (CSR). Sebelas Maret University.

Susana, A., Mustofa, \& Karimullah. (2020). The use collaborative strategy reading to improve students' reading comprehension at the fourth semester students of the deparment of English education in academic year 2019/2020. Universitas Islam Malang. 